\title{
Paradygmat kontynuacji i zmiany - generalną przesłanką scholiologii i reform edukacyjnych
}

\section{Wstęp. Geneza szkoły}

Do najstarszych instytucji stworzonych przez ludzkość należy tuż po świątyni właśnie szkoła. Świadczy to o tym, że zaspokajała ona bardzo ważne dla ludzi ponadczasowe potrzeby.

Najdawniejsze wzmianki o szkole sięgają czasów starożytnych, a nawet prehistorycznych. Pierwsze szkoły powstawały w Chinach, Mezopotamii i Egipcie. Olbrzymi wpływ na teorię i praktykę wychowania w Chinach wywarł Konfucjusz (551-479 p.n.e.). Napisana przez niego Księga Li (obrzędów) dowodzi, że ideał wychowania postulował opanowanie sześciu cnót: mądrości, uczynności, dobroci, sprawiedliwości, wierności i zgody. W tych samych mniej więcej czasach co w cywilizacji chińskiej, a nawet prawdopodobnie nieco wcześniej, powstawały pierwsze szkoły w cywilizacji sumeryjskiej. Oprócz literatury pięknej, gramatyki i teologii, dzięki tym szkołom rozwijały się różne dziedziny wiedzy, szczególnie zaś botanika, zoologia, geografia, matematyka, geometria, a także astronomia.

Przejście Egiptu z ustroju pierwotnego do niewolniczego (w trzecim tysiącleciu p.n.e.) przyśpieszyło rozwój wychowania, a zwłaszcza kształcenia w różnych typach szkół, mających na celu przygotowanie młodych chłopców do pracy w różnych zawodach. W późniejszych 
czasach absolwenci uczyli się w jednej ze szkół kapłańskich estetyki, filozofii, prawa i zasad administrowania.

Największy i bezpośredni wpływ na rozwój szkół oraz całej kultury europejskiej wywarła starożytna Grecja. W dziejach wychowania europejskiego można wyróżnić dwa systemy: system spartański, w którym bardziej podkreślano znaczenie wychowania fizycznego i moralnego oraz system ateński, w którym większą uwagę zwracano na kształcenie umysłowe i estetyczne. Dążenie do tego, co najlepsze określano mianem kalokagatii (piękno, dobro).

Początków szkól ateńskich (wyraz szkoła pochodzi od greckiego schole $=$ spokojny czas) historycy wychowania dopatrują się w ustawodawstwie ateńskiego męża stanu, poety i reformatora Solona (ok. 635560 p.n.e.). Chłopcy i dziewczęta rozpoczynali naukę w 7 roku życia. Uczęszczali do szkół prywatnych, odprowadzani przez niewolników zwanych pedagogami. Uczyli się w nich czytania, pisania, rachunków i muzyki.

Sokrates (436-338 p.n.e.), podobnie jak nieco później Platon i Arystoteles, założył w 390 roku p.n.e. własną szkołę wyższą, którą zgodnie z tradycją nazwano Akademią Platońską. Dzieci codziennie uczęszczały do szkoły, w której uczyły się matematyki, historii, filozofii i astronomii, a także retoryki, gimnastyki i muzyki.

Do wielkich ośrodków kultury i nauki hellenistycznej należały nadal Ateny, a następnie Aleksandria, gdzie w 280 roku p.n.e. powstał pierwszy instytut naukowo-badawczy pod nazwą „Muzeum”, zorganizowany pod wpływem działalności naukowej Liceum Arystotelesa.

Szkolnictwo grecko-rzymskie stało się pierwowzorem w następnych wiekach. Większość charakterystycznych rysów i wzorców europejskiego wychowania szkolnego w późniejszych stuleciach wywodzi się ze szkół greckich i rzymskich.

\section{Paradygmat kontynuacji i zmiany generalną przesłanką filozofów chińskich, sumeryjskich, egipskich, greckich i rzymskich oraz współczesnych teoretyków edukacji}

Geneza i rozwój szkół chińskich, sumeryjskich, egipskich, greckich i rzymskich, niezależnie od różnic cywilizacyjnych, to znaczy politycznych, religijnych, kulturowych, czy językowych podlegały paradygmatowi kontynuacji i zmiany. Pomimo wielu przemian, w różnych 
epokach kontynuowano większość idei, wartości, wzorców i doświadczeń ponadczasowych, potrzebnych kolejnym generacjom, zarówno młodszym jak i starszym. Natomiast w tych samych czasach w edukacji szkolnej rezygnowano z dyscyplin, przedmiotów i konkretnych treści, które się zdezaktualizowały, po prostu przestały być potrzebne kolejnym pokoleniom. Przemiany te dokonywały się różnymi drogami. Przewodnią rolę odgrywali filozofowie i kapłani, którzy współtworzyli pierwsze szkoły, czy akademie. Proces kontynuacji i zmian w szkolnictwie trwał przez całe średniowiecze, oświecenie i reformację. We współczesnych czasach dynamicznego rozwoju kapitalizmu nastąpiło znaczne przyśpieszenie przemian w szkolnictwie, zwłaszcza zawodowym. Szczególnie intensywnie rozwijało się szkolnictwo zawodowe.

Należy jednak podkreślić, że szkolnictwo w różnych krajach przeżywało w niektórych okresach dłużej lub krócej trwające kryzysy, spowodowane przede wszystkim nieprzestrzeganiem paradygmatu kontynuacji i zmiany.

Każda reforma edukacji to bardzo poważna operacja nażywym organizmie, którym są przede wszystkim nasze dzieci, aktualni uczniowie. W przygotowaniu i przeprowadzeniu reformy powinni brać aktywny udział nie tylko politycy, lecz przede wszystkim eksperci - kompetentni uczeni i praktycy, zarówno nauczyciele jak i rodzice. Reformy szkolne należy przeprowadzać rzadko i tylko w przypadku absolutnej konieczności, po dokonaniu obiektywnej i rzetelnej diagnozy, zarówno mocnych jak i słabych stron dotychczasowego funkcjonowania całego ustroju szkolnego, z uwzględnieniem zarówno przewidywanych kosztów jak i korzyści - efektów.

Przemiany dokonujące się współcześnie w szkolnictwie w krajach na różnych kontynentach trwają ustawicznie. Wymagają one pogłębionej, wieloaspektowej, obiektywnej oceny, opartej na paradygmacie kontynuacji i zmiany.

W pewnym sensie przykładem takiego studium diagnostycznego były badania prowadzone w ramach Centralnego Programu Badań Podstawowych realizowane pod kierunkiem naszego Jubilata, prof. zw. dr hab. Jerzego Niemca (CPBP-08-17), w latach 1996-1999, które stały się podstawą ostatniej reformy całego systemu oświaty w 1999 roku. Dokonano wówczas reformy ustrojowej systemu edukacji szkolnej w Polsce. W jej wyniku okres nauki w szkole podstawowej został 
skrócony z 8 do 6 lat. Następnym etapem edukacji stały się obowiązkowe 3-letnie gimnazja. Po ich ukończeniu uczniowie mogli kontynuować naukę w:

- 3-letnich liceach ogólnokształcących,

- 3-4-letnich technikach zawodowych,

- 3-letnich zasadniczych szkołach zawodowych.

Decyzja o powołaniu gimnazjów od początku budziła wiele kontrowersji, zwłaszcza mając na względzie tworzenie od podstaw nowoczesnej bazy lokalowo-laboratoryjnej i przygotowanie dla tego szczebla edukacji kompetentnych kadr. Obawiano się też wzrostu agresji wśród uczniów w tym trudnym dla nich okresie rozwojowym. Po kilku latach od powstania gimnazjów założone zasadnicze cele reformy, dzięki olbrzymiemu nakładowi sił i środków zostały w przeważającej mierze zrealizowane.

W latach 2018/2019, wychodząc głównie z przesłanek politycznych, podjęto kolejną reformę całego systemu edukacji szkolnej.

Struktura szkół publicznych po zmianach, od 1 września 2019 roku obejmuje 8-letnią szkołę podstawową, 4-letnie liceum ogólnokształcące, 5-letnie technikum, 3-letnią branżową szkołę I-stopnia, 3-letnią szkołę specjalną przysposabiającą do pracy oraz 2-letnią branżową szkołę II-stopnia-szkołę policealną.

Jako najbardziej odpowiedni moment dla przeprowadzenia tak złożonej reformy systemu edukacji wybrano niż demograficzny, obejmujący młodzież na progu szkoły podstawowej i liceum. Tak złożoną reformę ustroju szkolnego przygotowano w pośpiechu. Przy czym zasadnicze cele i założenia organizacyjne i programowe nie konsultowano z kompetentnymi specjalistami, którzy teorii i praktyce funkcjonowania systemu szkolnego poświęcili wiele lat.

Najwyższa Izba Kontroli zarzuciła Ministerstwu Edukacji Narodowej nierzetelne przygotowanie i wdrożenie reformy edukacji szkolnej. Zauważono szereg niedociągnięć, jak chociażby brak porządnych analiz finansowych i organizacyjnych skutków reformy. Poważne zastrzeżenia pojawiły się także wobec procesu przygotowania nowych podstaw programowych. Przypomnijmy, że jej najważniejszym założeniem była likwidacja gimnazjów i wydłużenie nauki w szkołach podstawowych do ośmiu lat. W ocenie NIK sposób, w jaki minister edukacji narodowej przygotował i wprowadził zmiany w systemie oświaty, był nierzetelny. 
Izba zwróciła uwagę, m.in. na fakt, że brak było pełnych danych i informacji na temat kosztów reformy.

Przed podjęciem tak ważnej dla młodego pokolenia Polaków reformy zespół najbardziej kompetentnych ekspertów, z udziałem uczonych i praktyków powinien był obiektywnie ustalić - co w dotychczasowym systemie edukacji szkolnej funkcjonowało dobrze i należało kontynuować, a co źle, nieskutecznie i powinno być zmienione bądź skorygowane.

Obecnie na zmianę głównych założeń prowadzonej aktualnie reformy edukacji szkolnej - moim zdaniem - jest raczej za późno. Pozostaje nam troska o zapewnienie wysoko wykwalifikowanej kadry nauczycielskiej dla dwóch równoległych oddziałów w 4-letnich liceach ogólnokształcących (po szkole podstawowej i gimnazjach). Nie mniej ważnym zadaniem będzie efektywne wykorzystanie nowoczesnej bazy dydaktyczno-laboratoryjnej, którą z dużym nakładem środków udało się dotychczas stworzyć dla likwidowanych obecnie gimnazjów.

\section{Paradygmat optymalnej zmiany generalną przesłanką nauki o szkole czyli scholiologii}

Na każdym kontynencie, czy w państwie system edukacyjny kształtował się pod wpływem różnych prądów filozoficznych i ideologicznych oraz przemian społeczno-gospodarczych. Niemniej jednak można wskazać na wiele uniwersalnych paradygmatów ustroju szkolnego, spełniających podobne lub takie same funkcje i zadania w danym okresie, które mogą być punktem wyjścia dla tworzenia teorii szkoły i optymalnych zmian systemu organizacyjnego czy programów nauczania i wychowania. Uogólniając, można stwierdzić, że w dotychczasowej historii różnego typu szkół zawarty jest wielki potencjał wiedzy i doświadczenia kolejnych pokoleń, którego nie wolno zaprzepaścić.

W monografii Nauczyciele przyszłej szkoły napisałem:

nadszedł czas, aby nauka o teoretycznych i praktycznych zagadnieniach działalności szkoły uzyskała nazwę własną. Proponuję więc nazwę scholiologia, od greckiej nazwy scholio - szkoła i logos - nauka, pojęcie, słowo, której przedmiotem byłyby badania działalności szkoły jako instytucji społecznej, jej systemu organizacyjnego, funkcji i programów 
dydaktyczno-wychowawczych i kulturalnych w trzech wymiarach czasowych: przeszłości, teraźniejszości i przyszłości.

Bardzo ważnym - moim zdaniem - argumentem przemawiającym za tworzeniem scholiologii, czyli nauki o szkole może być to, że wiele subdyscyplin pedagogicznych ma swoją nazwę naukową. To samo dotyczy wielu dziedzin świata przyrody czy życia społecznego, często o wiele mniej znaczących. Natomiast szkoła, najstarsza i niewątpliwie najważniejsza z nich, nie posiada własnej autonomicznej czy interdyscyplinarnej nauki.

Zatem scholiologia, czyli nauka o szkole mogłaby przyczynić się do tworzenia nowej teorii szkoły, zwiększenia zainteresowania uczonych reprezentujących różne dyscypliny naukowe samą szkołą, poszukiwaniem nowych możliwości jej odrodzenia bądź doskonalenia. Chodzi o kompleksowe badania szkoły jako systemu holistycznego, a zarazem otwartego na potrzeby uczniów i nowe wyzwania cywilizacyjne, zwłaszcza społeczne.

Celem dalekosiężnym, a raczej misją scholiologii powinno być odrodzenie człowieka pod względem intelektualnym, moralnym i kulturalnym. Przedmiotem badań scholiologii powinno być szeroko rozumiane szkolnictwo, a także poszczególne szkoły, ich systemy i mikrosystemy wewnątrzszkolne oraz infrastruktura zewnętrzna.

Z powyższej koncepcji scholiologii wynika, że nauka o nowoczesnej szkołę powinna mieć charakter interdyscyplinarny, wielofunkcyjny i polimetodyczny. Szczególną uwagę powinna poświęcić rozwojowi organizacyjnemu oraz wprowadzaniu do szkół innowacji naukowych, technicznych i pedagogicznych, jak również nowatorskich rozwiązań praktycznych.

Szkoła jutra lub przyszłości powinna obejmować zmiany zarówno w systemie (przestrzeni) edukacji wewnątrzszkolnej, równoległej i wirtualnej (rycina 1).

Prezentowane powyżej trzy przestrzenie edukacyjne współczesnej szkoły, jak i dyscypliny naukowe, na których bazuje scholiologia potwierdzają szczególną rolę teorii konwergencji.

1 J. Kuźma, Nauczyciele przyszłej szkoły, Wydawnictwo Naukowe Akademii Pedagogicznej w Krakowie, Kraków 2000, s. 224. 
Rycina 1. Trzy przestrzenie nowej edukacji szkolnej

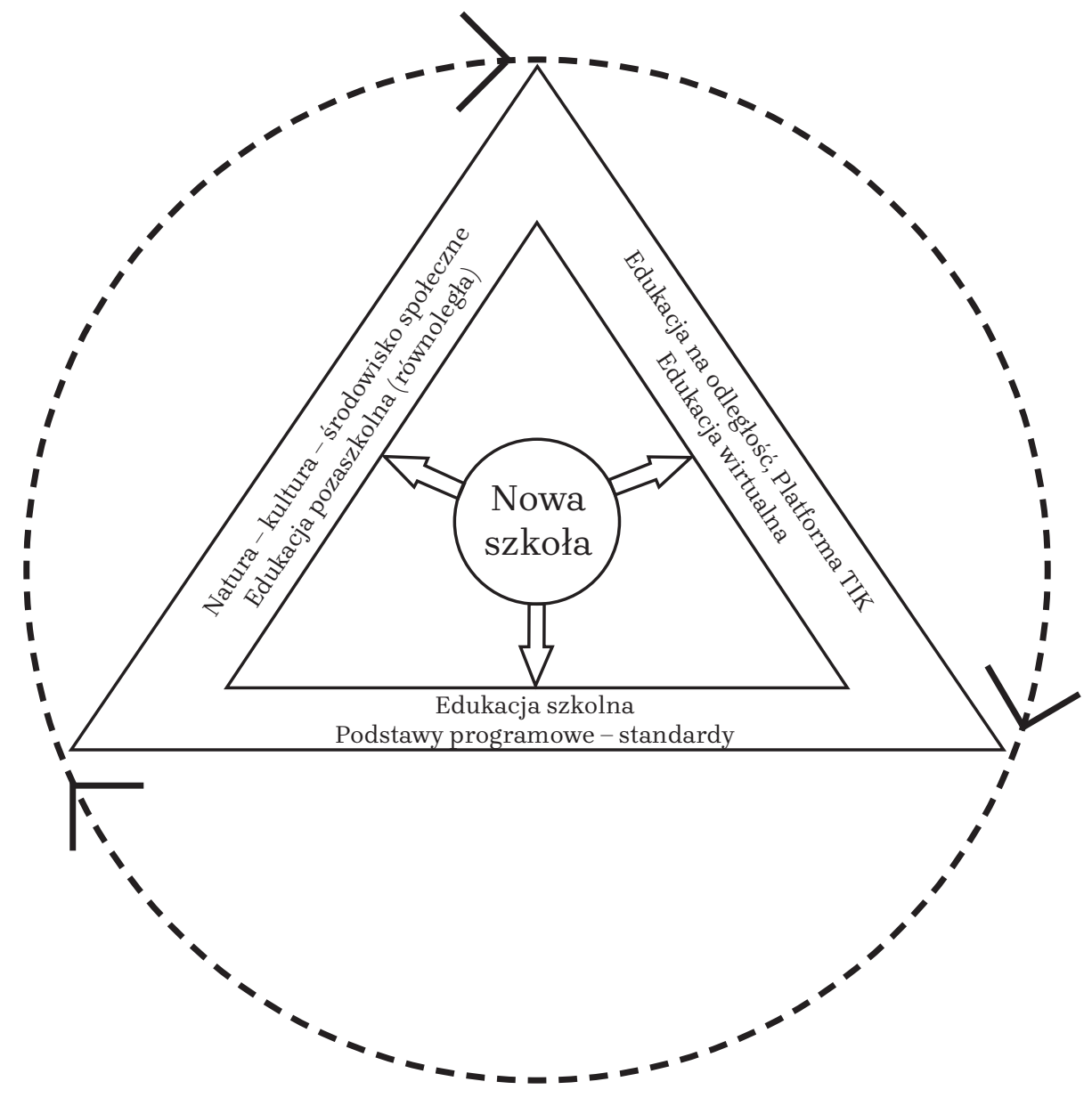

Źródło: opracowanie własne.

W anglojęzycznej pracy zbiorowej: The School of Tomorrow Centred on Pupils ${ }^{2} \mathrm{w}$ moim artykule uzasadniłem tezę, że pomiędzy takimi podstawowymi przestrzeniami edukacyjnymi nowoczesnej szkoły, jak wewnątrzszkolna, pozaszkolna i medialna zachodzi bardzo ważny proces konwergencji, polegający na wzajemnym przenikaniu,

2 J. Kuźma, From traditional to more student-centred future school, [w:] J. Kuźma, J. Pułka (red.), The School of Tomorrow Centred on Pupils, A.F.M. Publishing House, Kraków 2015, s. 23. 
scalaniu i wzmacnianiu elementarnych idei, wartości, innowacji i informacji, który prowadzi do pogłębionej analizy i kreuje proces ich syntezy. Dzięki temu możliwy jest synergiczny efekt, który w rezultacie składa się na nowe jakościowe efekty, holistycznie postrzeganego procesu edukacji dzieci i młodzieży (patrz rycina 1).

Nowoczesna szkoła powinna być bardziej skoncentrowana na uczniach. W takiej placówce chodzi przede wszystkim o to, aby uczniowie byli traktowani przez nauczycieli-wychowawców podmiotowo, a nie przedmiotowo, przyjaźnie, a nie instrumentalnie. Nie oznacza to pajdocentryzmu, lecz szanowanie tożsamości i godności każdego ucznia. Zmiany szkoły klasycznej na nowoczesną powinny bazować na poznawaniu potencjału intelektualnego i emocjonalnego każdego ucznia, jego zainteresowań oraz motywacji do zdobywania wiedzy i opanowania konkretnych umiejętności.

Kompetentni programiści i nauczyciele bloków przedmiotowych oraz poszczególnych przedmiotów powinni ustawicznie śledzić za aktualnymi osiągnięciami nauki, techniki i praktyki w swojej dziedzinie wiedzy.

Tylko taka szkoła może zapewnić harmonijny rozwój każdego ucznia, odpowiadający jego potencjałowi intelektualnemu i emocjonalnemu oraz wysokim walorom moralnym.

Wymaga to od kadry nauczycielskiej wysokich kompetencji, zwłaszcza w zakresie znajomości uczniów, nauczanej dyscypliny (przedmiotu) oraz wysokiej kultury osobistej. Nauczyciel przyszłej szkoły powinien pełnić rolę animatora rozwoju uczniów nie tylko w środowisku szkolnym, lecz i ojczyźnianym i ogólnoludzkim.

\section{Nauka o szkole, czyli scholiologia w opinii wybitnych znawców edukacji szkolnej}

W odpowiedzi na ostatnią monografię Scholiology w wersji anglojęzycznej (drukowanej i elektronicznej) oraz Scholiologia, polskojęzycznej (elektronicznej) otrzymałem ponad 15 opinii. Chciałbym zacytować kilka z nich poświęconych nauce o szkole, czyli scholiologii, uczonych cieszących się wysokim autorytetem.

$\mathrm{Na}$ szczególną uwagę zasługuje recenzja kolejnych edycji monografii Nauka o szkole czyli scholiologii ś.p. Profesora Kazimierza Denka (1932-2016). Moim zdaniem, świadczy ona o tym, że zarówno z punktu 
widzenia przeszłości, teraźniejszości, jak i przyszłości szkoła i szkolnictwo trwały i rozwijały się zgodnie z paradygmatem kontynuacji i zmiany. Jak stwierdził prof. K. Denek: „jest to praca, która odznacza się w znacznym stopniu takimi walorami jak: aktualność i ważność w sensie społecznym, poznawczym, metodologicznym i utylitarnym podejmowanej w niej problematyki; innowacyjnością, obiektywizmem naukowym i wiarygodnością". Nie można obejść się bez tej książki w kształceniu i doskonaleniu nauczycieli. Stanowi ona interesujące wprowadzenie do edukacji i nauk o niej.

Warto nadmienić, że scholiologia jako nauka o szkole znalazła już swoje miejsce w Encyklopedii pedagogicznej XXI wieku, pod redakcją naukową Tadeusza Pilcha ${ }^{3}$.

Z kolei prof. Zbigniew Kwieciński - nestor polskich pedagogów i socjologów edukacji, po otrzymaniu mojej książki Nauka o szkole napisał: „Dziękuję Ci bardzo za prezent i gratuluję wydania tak ambitnie pomyślanej i zredagowanej monografii, odznaczającej się szeroką erudycją i zdolnością do syntez, żywością i kreatywnością umysłu". W odpowiedzi na ostatnie wydanie Scholiology, w języku angielskim i polskim prof. Z. Kwieciński napisał: „Dziękuję Ci bardzo za obdarzenie mnie książką Scholiology. Gratuluję Ci jej wydania. Zapewne przyniesie Ci ona uznanie u czytelników całego świata, czego Ci szczerze życzę".

Podobnie prof. Janusz Tazbir (1927-2016), jeden z najwybitniejszych polskich historyków i znawców kultury, napisał: „nadesłaną mi książkę «Nauka o szkole. Studium monograficzne» przeczytałem z dużym zainteresowaniem. Jest to praca nowatorska, otwierająca nowe perspektywy edukacyjne na wiek XXI i na pewno doczeka się wielu recenzji (i polemiki) w fachowym czasopiśmiennictwie".

$\mathrm{Na}$ zakończenie chciałbym zacytować $\mathrm{w}$ oryginale fragment pisma prof. Marka Bray'a, przewodniczącego World Council Comparative Education Societies, a zarazem dyrektora Comparative Education Research Centre, The University of Hong Kong, dotyczący odpowiedzi na ostatnią monografię Scholiology:

3 T. Pilch, Encyklopedia pedagogiczna XXI wieku, Wydawnictwo Akademickie „Żak”, Warszawa 2006, s. 673-675.

4 J. Kuźma, Nauka o szkole. Studium monograficzne. Zarys koncepcji, Oficyna Wydawnicza „Impuls”, Kraków 2005 - wyd. I; 2008 - wyd. II i III; 2011 - wyd. IV. 
It was indeed a pleasure to hear from You after a long time, and to receive your book Scholiology. Many thanks!. I have placed in our University library, so that more people can have access to it. From the book J can see that you continue to contribut activity to the field of education and through it, to the world. My congratulation. (...) We also have much activity in our Comparative Education Research Centre at the University of Hong Kong.

\section{Konkluzja}

1) Reforma systemu edukacji szkoły powinna konsekwentnie przestrzegać paradygmatu kontynuacji i zmiany, to znaczy kontynuować wszystko, co sprawdziło się w dotychczasowej praktyce oraz ustawicznie wzbogacać programy nauczania i wychowania o nowe treści, wartości i doświadczenia; natomiast konsekwentnie zmieniać to, co jest niezgodne $\mathrm{z}$ aktualną nauką i praktyką pedagogiczną, w sferze organizacyjnej i programowej, przede wszystkim zaś zdezaktualizowaną wiedzą i metodami nauczania.

2) W związku z powyższym, racjonalna i skuteczna reforma szkoły powinna być poprzedzona gruntowną analizą i diagnozą wszystkich sfer dotychczasowej działalności szkoły w sferze organizacyjnej i programowej, zarówno dydaktycznej jak i wychowawczej.

3) W przygotowaniu i przeprowadzeniu kompleksowej, a zarazem efektywnej reformy szkoły i szkolnictwa nieodzowna będzie zarówno teoria jak i praktyka dotychczasowego funkcjonowania systemu szkolnego. Dlatego bardzo cennym źródłem stale aktualizowanej teorii i praktyki funkcjonowania szkolnictwa w naszym kraju i za granicą może być scholiologia, czyli nauka o szkole.

\footnotetext{
Abstract

The concept of paradigm has its origin in ancient Greece. Plato understood a paradigm as an idea or form, while Aristotle gave it the meaning of a particular pattern or model. The school, alongside the Temple, is the oldest social institution that meets the very important developmental needs of the young generations of society. It is shown in the article, based on the genesis of the school in various countries of the world, how in the history of the school there were periods of both development and stagnation. Major school system and program
} 
changes were carried out in accordance with the general principle of continuation and change. This means that everything that has worked well in the current practice of the school's activities should be continued and the curricula and upbringing should be constantly enriched with new content, values, and experience, while consistently changing what is incompatible with current science and practice in programmes and the organizational sphere and, above all, outdated knowledge and teaching methods. This general rule should also apply to the reform of the Polish school system introduced in 2019. Only by observing the general principle of continuation and change can school reform achieve its intended goals. The fact that the optimal change paradigm is the guiding thought of learning about school or scholiology deserves to be emphasized in the presented article. The concept of scholiology met with positive feedback from many Polish scholars involved in school education, as well as Professor Mark Bray, Chairman of the World Council of Comparative Education Societies (University of Hong Kong, 2019).

\section{Bibliografia}

Kuźma J., Optymalizacja systemu pedagogicznego kształcenia, doksztatcania i doskonalenia nauczycieli, PWN, Warszawa - Kraków 1993.

Kuźma J., Nauczyciele przyszłej szkoły, Wydawnictwo Akademii Pedagogicznej w Krakowie, Kraków 2000.

Kuźma J., Nauka o szkole. Studium monograficzne. Zarys koncepcji, Oficyna Wydawnicza „Impuls”, Kraków 2005 - wyd. I; 2008 - wyd. II i III; 2011 - wyd. IV.

Kuźma J., Morbitzer J., Edukacja - szkoła - nauczyciele. Promowanie rozwoju dzieci, Wydawnictwo Akademii Pedagogicznej w Krakowie, Kraków 2005.

Kuźma J., Pułka J. (red.), Ku dobrej szkole skoncentrowanej na uczniach, Oficyna Wydawnicza AFM, Kraków 2014.

Kuźma J., From traditional to more student-centred future school, [w:] J. Kuźma, J. Pułka (red.), The School of Tomorrow Centred on Pupils, AFM Publishing House, Kraków 2015.

Kuźma J., Scholiology. The General Study of School, Oficyna Wydawnicza „Impuls”, Krakow 2018.

Kuźma J., Scholiologia, Generalne Studium Szkoły, Oficyna Wydawnicza „Impuls”, Kraków 2018.

Litak S., Historia wychowania, t. 1, WAM „Ignatianum”, Kraków 2004.

Pilch T., Encyklopedia pedagogiczna XXI wieku, Wydawnictwo Akademickie „Żak”, Warszawa 2006. 
Wołoszyn S., Dzieje wychowania i myśli pedagogicznej w zarysie, PWN, Warszawa 1964.

\section{Netografia}

https://pl.wikipedia.org/wiki/Reforma_systemu_o\%C5\%9Bwiaty_ z_1999_rok

https://serwisy.gazetaprawna.pl/edukacja/artykuly/1413629,niedostateczna-reforma-edukacji-pod-lupa-nik-kontrola.html

https://www.gov.pl/web/edukacja

https://www.nik.gov.pl/aktualnosci/reforma-oswiaty-w-czescisfinansowana-przez-samorzad.html 